\title{
FEE SHIFTING AND THE IMPLEMENTATION OF PUBLIC POLICY
}

\author{
Frances KahN Zemans*
}

I

\section{INTRODUCTION}

The American legal system is structured so that private citizens by invoking the law play a critical role in its enforcement. Any new authoritative rule, whether statutory, judicial, or administrative, merely provides potential opportunities. In practice, conferred rights are contingent upon the factors that promote or inhibit mobilization of the law. ${ }^{1}$ With enforcement highly dependent upon initiation of the legal process by citizens, the factors that influence their decisions to invoke the law are centrally important to the implementation of public policy. The American rule on attorney fee allocation is one such factor, for it determines the direct financial burdens of legal representation.

The distribution of legality occurs largely outside public forums and without the intervention of professional counsel. It proceeds by way of voluntary compliance and through the assertion of legal rights by potential beneficiaries of the law. In most cases the matter continues no further, because of satisfaction of the demand or a decision that further pursuit of the issue is not worth the trouble. ${ }^{2}$ To say, however, that neither courts nor lawyers are directly involved in most mobilization of the law is not to say that the nature of courts and the structure of the legal profession play no role. For once the legal potential of an issue is recognized and asserted, the threat of more formal legal action and the attendant power of the state are incorporated into any continuing discussion. Therefore, substantive laws and procedural rules do count-and they count well beyond the courtroom and even the law office. This perspective is compatible with Mnookin and Kornhauser's view that private ordering - the bargaining process-is affected by legal rules and procedures, that is to say, what would happen in court if a case were to be filed and to proceed to disposition. ${ }^{3}$ Thus, for example, the threat of formal legal

Copyright (C) 1984 by Law and Contemporary Problems

* American Judicature Society, Chicago, Illinois. The author wishes to thank Mark Petracca and Richard Heimedinger for their researci assistance and Thomas Davies, Bryant Garth, Robert Kagan, Thomas Rowe, Stephen Wasby, and Charles Wolfram for their comments on an earlier draft.

1. Recognition of the important role of legal mobilization in enforcement can be seen in the continuing debate over congressional and/or judicial authorization of private causes of action. This debate continues precisely because of the impact that private legal actions can have on the implementation of public policies.

2. For an extended discussion of the factors that influence this decisionmaking process, see Zemans, Framework for Analysis of Legal Mobilization: A Decision-Making Model, 1982 AM. B. FOUND. RESEARCH J. 989.

3. See Mnookin \& Kornhauser, Bargaining in the Shadow of the Law, 88 YALE L.J. 950 (1979). 
action affects negotiated settlements of personal injury cases. ${ }^{4}$ This is true in other areas of the law as well.

However, the threat to use the law is a hollow one and therefore may not even be made, when it is clear that the costs and complexity of pursuing a claim are beyond the means or will of those who believe they have been wronged. Moreover, the power of the implicit or explicit threat to employ legal services and/or formal legal structures can be diminished for reasons other than the capabilites (financial and otherwise) of the one asserting a claim. The use of lawyers and courts may, more generally, simply not be worth the time, effort, and cost. For example, claims of less than several thousand dollars are rarely litigated, making the threat of doing so a rather empty gesture. ${ }^{5}$ In addition, unlike large monetary claims that may be pursued on a contingency fee basis, suits seeking equitable relief of even a very serious nature are inhibited by the anticipated high legal fees. This is more likely to be true in the United States than in other Western nations. The difference is due neither to a greater proportion of small claims nor to higher costs of legal services here than elsewhere (although both of these may indeed exist). Rather, it is a function of a mechanism for the payment of attorney fees so unique that it is known as the "American rule."

\section{The American Rule}

The United States is the only common law jurisdiction in which attorney fees do not follow the event. Absent an express statutory exception, each party must bear the total expense of compensating his or her own attorney. The common law rule that one whose rights have been violated should be made whole does not operate, for one's recovery here (whether monetary or in the form of equitable relief) is diminished by the amount paid in legal fees necessary to successfully pursue a valid legal claim. It is this peculiarity that led one commentator to argue that in the United States it is irrational to pay any debt in full. ${ }^{6}$

The history of the American rule is extremely foggy. It is certainly more than slightly curious that this particular structural component (the indemnity rule) is not included among the many aspects of the English legal system that are at the core of American law. Actually, it is not completely clear how, where, or when various parts of the English legal system were adopted in the American colonies and later in the states. That history is both too unclear and too diverse to consider here.

It can be said that, at least at the national level, the American rule was presumed to be the general practice before the nineteenth century, for in 1796 the

4. See H. Ross, Settled Out of Court (1970).

5. The exception of small claims courts only serves to prove the rule, with the establishment of a specialized structural mechanism reflecting recognition of the general system's inability to meet a significant legal demand. Indeed the documented record of the operation of small claims courts as forums for debt collections further substantiates the point. Both the extensive use of default judgments and the economies of scale enjoyed by retailers and collection agencies avoid the problems most have in pursuing small claims in court.

6. See Leff, Injury, Ignorance and Spite-The Dynamics of Coercive Collection, 80 YALE L.J. 1 (1970). 
United States Supreme Court disallowed the shifting of counsel fees that had been granted by a lower court. The Court stated that

the general practice of the United States is in opposition to [the indemnity rule]; and even if that practice were not strictly correct in principle, it is entitled to the respect of the court, till it is changed or modified by statute. ${ }^{7}$

The force of time has done much to solidify the position of the American rule at the state and national levels. ${ }^{8}$ Recent statutory exceptions to the rule are still considered exceptions, and the contemporary judiciary no longer questions the "correctness in principle" of the American rule. In fact, the Supreme Court now puts forth at least three arguments in favor of it: first, "since litigation is at best uncertain one should not be penalized for merely defending or prosecuting a lawsuit"; second, "the poor might be unjustly discouraged from instituting actions to vindicate their rights if the penalty for losing included the fees of their opponent's counsel"; and third, "the time, expense, and difficulties of proof inherent in litigating the question of reasonable attorneys' fees would pose substantial burdens for judicial administration."'9

Even the limited available history of the origins of the American rule makes it clear that these are post hoc arguments made in defense of the now long-established practice. Further, they are not by themselves very persuasive. There is no real evidence to support these contentions, and even at the level of pure argument they are weak. Indeed, the access argument, that fee shifting would adversely discourage the poor from vindicating their rights, is made just as vigorously in opposition to the American rule. The most frequently voiced objection to the American rule is that the burden of their own potential legal fees inhibits the poor from asserting valid claims, particularly where the amount claimed does not justify a contingency fee arrangement (and most claims of the poor do not). As a result, the rights of the poor are left unvindicated. Indeed, this argument can be pursued one step further to assert that by discouraging the poor from taking legal action the American rule has the effect of actually encouraging violations of their rights: Of course, the same could be asserted regarding those rights of the population as a whole that involve only small sums or equitable claims.

As can be seen from the arguments both for and against the American rule, the role of this seemingly minor structural variable turns out to be a rather complicated issue. ${ }^{10}$ Only recently has its impact on access to the justice system and on

7. Arcambel v. Wiseman, 3 U.S. (3 Dall.) 306 (1796). It is at least a bit curious that the lower court did not adhere to this "general practice." Unfortunately there are no records of the lower court opinion that might allow further inquiry.

8. See Leubsdorf, Toward a History of the American Rule on Attomey Fee Recovery, LAW \& COMTEMP. Probs., Winter 1984, at 9.

9. Fleischman Distilling Corp. v. Maier Brewing Co., 386 U.S. 714, 718 (1967).

10. To the extent that any attention has been accorded to the effects on legal action of paying one's own attorney fees, it has been concentrated on the choice between settlement and litigation, largely ignoring the impact on legal mobilization more generally. See e.g., Blankenburg, Legal Insurance, Litigant Decisions and the Rising Caseload of Courts: A West German Study, 16 LAlw \& Soc'Y REVIEw 601 (1981-82); Shavell, Suit, Settlement and Trial: A Theoretical Analysis Under Altemative Methods for the Allocation of Legal Costs, 11 J. Legal STud. 55 (1982). Ehrenzweig's calls for fee shifting are exceptions. See Ehrenzweig, Reimbursement of Counsel Fees and the Great Society, 54 CALIF. L. REV. 792 (1966); Enrenzweig, Shall Counsel Fees Be Allowed?, 26 CALIF. ST. B.J. 107 (1951). 
the distribution of legality begun to receive serious scholarly attention. " Nevertheless, courts and legislatures continue to fashion substantial exceptions to the American rule without rejecting outright either the rule or its validity. These exceptions have been created-as is typical of changes in legal structures-in response to political demands and in furtherance of well-defined public policy goals.

This article, having briefly traced the historical background of the American rule, will examine the judicial and legislative creation of exceptions to the rule. The articulated normative purposes of these exceptions are to protect the integrity and efficiency of the courts, to facilitate access to the legal process, and to encourage the enforcement of certain substantive laws. Unfortunately, as this review of the rule makes clear, there is no evidence as to the effects of the American rule, or any of the exceptions, on these goals. Thus, judgments about the American rule must await answers to these empirical questions.

\section{III}

\section{Exceptions to the American Rule as Public Policy}

Exceptions to the American rule can be readily dichotomized according to source, strategy, and policy goal. The courts, the source of the earliest exceptions, adopted fee shifting as a punitive measure to ensure the integrity of the judicial process. Legislatures, on the other hand, have employed fee shifting as an incentive to encourage enforcement of the law. In this scheme, fee shifting is typically uni-directional and pro-plaintiff. It is a means by which legislatures eliminate or minimize the economic disincentives that inhibit citizens from initiating legal action to obtain the benefits provided by law. In the aggregate, these demands for compliance have the effect of furthering enforcement of the laws by facilitating citizen participation in the legal process. ${ }^{12}$ Each of the policy goals-integrity of the judicial process and enforcement of the law-will be considered in turn.

\section{A. Integrity of the Judicial Process as Policy Goal}

Fee shifting has always been allowed by judicial discretion as a punitive measure against the filing of frivolous or bad faith suits. ${ }^{13}$ Attorney fees may be awarded to prevailing parties whose opponents have acted in bad faith, vexa-

11. The various arguments for and against the American rule and alternative forms of fee shifting are described and analyzed with great proficiency in other articles in this symposium: In parricular, see Rowe, Predicting the Effects of Altomey Fee Shifling, LAW \& CONTEMPORARY PROBS., Winter 1984, at 139.

12. The legislative histories of administrative agencies and of the development of private causes of action similarly reflect attempts to encourage enforcement. See Stewart \& Sunstein, Public Programs and Private Rights, 95 HaRv. L. Rev. 1193 (1982).

13. However, there is no evidence of how often fee shifting is imposed as a punitive measurc. If judicial imposition of sanctions for failure to make discovery (under Rule 37 of the Federal Rules of Civil Procedure) is any indication, judges are quite reluctant to impose costs. See Federal Justice Research Program, Office for Improvement in the Administration of Justice, a Study of Sanctions FOR Discovery Abuse 117 (1979) [hereinafter cited as Federal JUSTICE ResearCH Program|; see also R. Rodes, K. Ripple \& C. MoOney, Sanctions Imposable for Violations of The Federal Rules OF Civil Procedure 85-87 (1981). 
tiously, wantonly, or for oppressive reasons. ${ }^{14}$ Consistent with the theme of sustaining the integrity of the judicial process, a party injured by willful violation of a writ of mandamus or contempt of court order may also recover damages, including attorney fees, from the recalcitrant party. ${ }^{15}$

As part of the concern for integrity of the judicial process, attention also has been given to judicial efficiency. For if the judicial system does not operate with at least a minimum of efficiency, it cannot perform its constitutional role. This efficiency may be considered a necessary, though not sufficient, prerequisite to the integrity of the judicial process. Most of the recent attention given to efforts to decrease the burden on the courts (or to increase their efficiency, depending on one's semantic preference) has focused on limiting jurisdiction, diverting minor cases, and decreasing delay. ${ }^{16}$ Only very limited recognition has been given to the fact that the American rule may itself be a source of inefficiency.

Concern with efficiency has been reflected in some discretionary fee shifting in cases where the use of dilatory actions by the defendant is designed to protract litigation until the plaintiff is worn to financial exhaustion. ${ }^{17}$ Fee shifting is justified in such cases because, "by affording a wealthy disputant unconscionable leverage over an impecunious adversary . . . the no-fee rule may foster the use of dilatory tactics."18 Of course, the alternative case of harassment by a wealthier plaintiff can also occur.

An extreme example of legal harassment facilitated by the American rule occurred in California after a biology professor testified at a public hearing against a private development because of the deleterious effects it would have on wetlands that provided refuge for numerous bird species. In response, the developer sued

14. See Hall v. Cole, 412 U.S. 1, 5 (1973).

15. See Public Participation in Federal Agency Proceedings Act of 1977: Hearings on S. 270 Before the Subcomm. on Administrative Practice and Procedure of the Comm. on the Judiciary, 95th Cong., 1st Sess. 677 (1977) (Awards of Attomeys' Fees in Federal Courts and by Federal Agencies, paper submitted by Henry Cohen, Legislative Attorney, Congressional Research Service). Another traditional exception to the American rule is the common fund doctrine. It differs from other exceptions in that it disperses the cost of legal services among all who share in the fund that has been created, increased, or protected and typically does not shift fees to the loser. See, e.g., Sprague v. Ticonic Nat'l Bank, 307 U.S. 161 (1939); Trustees v. Greenough, 105 U.S. 527 (1882).

16. Chief Justice Burger has, for example, expressed strong views on limiting jurisdiction, finding alternative mechanisms for the resolution of minor disputes, and the likely impact of both on delay. See How to Break Logjam in Courts, U.S. NEwS \& WORLD REP., Dec. 19, 1977, at 21. For a recent discussion of continuing efforts to promote alternatives to the public courts for so-called minor disputes, see Stanley, Minor Dispute Resolution, 68 A.B.A. J. 62 (1982). Delay is being addressed on a continuing basis in many quarters, including an American Bar Association Commission to Reduce Court Costs and Delays.

17. Although there is no empirical evidence available, the willingness of judges to exercise this discretion appears to be limited. Until such time as systematic evidence is gathered, conclusions about the effects of fee shifting remain speculative.

18. Cohen, supra note 15, at 689 (emphasis added). For lawyers working on an hourly fee basis there is an additional incentive (beyond aiding their clients) to use delaying tactics. An anecdote on point was told years ago to a Stanford Law School audience by a senior partner of the prestigious law firm of Cravath, Swaine and Moore:

I was born, I think, to be a protractor . . . I could take the simplest antitrust case and protract it for the defense almost to infinity . . . [One case] lasted 14 years . . . Despite 50,000 pages of testimony, there really wasn't any dispute about the facts . . . We won that case, and, as you know, my firm's meter was running all the time-every month for 14 years.

Those Lawyers, Time, Apr. 10, 1978, at 55, 59. 
for $\$ 80$ million on the grounds of deprivation of use of property for lawful purposes. Although the suit was unsuccessful, the five years of litigation cost the defendants close to $\$ 20,000$. Under the American rule, further litigation for malicious prosecution was the only option available to the defendants to recover the $\$ 20,000$ that it had cost them to exercise their rights ${ }^{19}$

One variation on the theme of delay is the abuse of discovery procedures and its contribution to the inefficiency of the judicial process. Nothwithstanding the benefits of discovery to the substance of a case, under the American rule economic incentives for some litigants (depending on certainty of success and staying power) and for hourly fee-for-service lawyers encourage more and greater discovery. Efforts to control discovery by the creation of sanction provisions, including a shifting of attorney fees, are doomed to minimal effectiveness as long as economic incentives operate as they do. ${ }^{20}$ In addition, there are two reasons that available sanctions are rarely used.

The first limitation on the imposition of sanctions for discovery abuse is their dependence on the initiation of a complaint by a lawyer operating in an adversary system-a lawyer who may have previously employed or subsequently wish to employ the same tactics. Secondly, the judge is forced to find actual abuse. That is much easier to do under conditions of refusal to obey a discovery order than it is for motions to request discovery. As a result, it is not surprising that the limited available empirical evidence indicates that judicial sanctions are more likely to be imposed for the former. ${ }^{21}$

The point is that delay tactics in general and excessive discovery in particular are difficult to control under a punitive scheme of discretionary fee shifting. ${ }^{22} \mathrm{By}$ virtue of the cost-bearing scheme dictated by the American rule, delay, particularly in low-risk cases, is less costly and is therefore encouraged. In contrast, it can be argued that in high risk cases fee shifting provides an economic disincentive to engage in delay. While such a disincentive would not eliminate these tactics, it would influence their use and thereby affect the efficiency of the judicial process ${ }^{23}$

It is possible that under a fee shifting rule a liable defendant in the run-of-themill case would be subject to delay tactics by the plaintiffs in an effort to increase fees and thus force a higher settlement. This problem is addressed in other juris-

19. See Diamond, Trial by Fire Lives on in Civil Suits, L.A. Times, Nov. 27, 1980, § 1, at 1, col. 1.

20. Justice Powell, joined by Justices Stewart and Rehnquist, opposed the adoption of sanction amendments to the discovery rules on the grounds that it would give the appearance of improvement without providing any, and thereby diminish pressure to institute needed changes. Amendments to the Federal Rules of Civil Procedure, 85 F.R.D. 521, $521-23$ (1980) (Powell, J., dissenting statement).

21. See Federal Justice Research Program, supra note 13, at 4.

22. Judge Milton Pollack, an outspoken critic of discovery abuse, has urged more active trial judge oversight of the discovery process to prevent the need for imposing sanctions. See Pollack, Discovery-lts Abuse and Correction, 80 F.R.D. 219 (1979). While some federal judges share this view, it has not yet influenced the behavior of most. See FEDERAL Justice Research PROGRAM supra note 13, at 32.

23. Efficiency and judicial integrity are not the only bases for promoting a reduction in delay and excessive discovery. An enforcement-related access to justice argument can also be made. For as delay and discovery contribute to an increase in the costs (financial and otherwise) of using the courts, they consequently reduce the effectiveness of the threat to do so and discourage compliance with the law. 
dictions by a mechanism limiting liability for attorney fees. ${ }^{24}$ Under the British indemnity rule, for example, a defendant at any time has the option of "paying in" an offer of a settlement. If the amount of the judgment does not exceed that offer the defendant need not pay any portion of the winning plaintiff's attorney fees incurred subsequent to the "payment in." Moreover, the plaintiff is liable for the defendant's "post-payment in" fees. ${ }^{25}$

A similar mechanism, intended to encourage settlements and avoid protracted litigation, exists under Rule 68 of the Federal Rules of Civil Procedure, which provides for an "Offer of Judgement." However, for unexplored reasons, including in part both established practice and uncertainty as to how courts would interpret Rule 68 (particularly whether costs awarded are to include attorney fees) this procedure is rarely invoked. ${ }^{26}$ Without cases, of course, the rule will not be interpreted, and that very uncertainty can be used to justify failure to invoke the rule. $^{27}$

The American rule on attorney fees may effect not only the length of each case, but also the number of cases litigated. With litigants responsible only for their own legal fees, as the amount claimed (and thus potential benefit) increases, the American rule encourages some categories of litigation and discourages others. With the risk limited to the fees of one's own attorney, a party is more likely to pursue doubtful claims than if additionally threatened with paying opponents' attorney fees. Therefore, the American rule provides economic incentives that promote higher risk and even spurious claims; defenses of questionable merit are similarly encouraged. For the same reasons the American rule arguably encourages the judgment-debtor not to pay settled claims, forcing the successful litigant to accept something less than the judgment or to sue for collection, which in turn increases the caseload. ${ }^{28}$

Certainly, the case for or against the American rule cannot be made on the basis of caseload without normative evaluations of the appropriate use of the courts, for fee shifting would be expected to encourage some kinds of cases and

24. Under an indemnity rule, successful defendants, like those in the California biology professor's case discussed previously, would be awarded fees and so would not need any special protection.

25. For a brief description of the payment-in system, see A. KIRALFY, The ENGLISH LEGal SYSTEM 369-70 (1960).

26. Wright and Miller conclude that attorney fees are not included as costs unless specifically mentioned in the offer. See 12 C. Wright \& A. Miller, Federal Practice and Procedure 57 (1973). That conclusion is consistent with the Supreme Court's interpretation of the statutory definition of the term "costs" as not including attorney fees. See Fleischmann Distilling Corp. v. Maier Brewing Co., 386 U.S. 714, 720 (1967); see also Note, Rule 68: A "New" Tool for Litigation, 1978 DukE L.J. 889. But see Preliminary Drafl of Proposed Amendments to the Federal Rules of Civil Procedure, 98 F.R.D. 339, 361-67 (1983) (proposed revision of Rule 68).

27. A variation on the offer of judgement described in Rule 68 was proposed by Judge Robert Keeton (then a Harvard law professor) to the ABA Action Commission to Reduce Court Costs and Delay. The proposal calls for a mandatory exchange of offers in money damage cases with costs and attorney fees to be borne by the party whose offer incorrectly estimates the value of the case as determined at trial. See Nejelski, Allocation/Fee Shifting/Sanctions in the Proposed Framework for Settlement (1980) (Memo to Commissioners, A.B.A. Action Commission to Reduce Court Costs and Delays). For a more detailed explanation of the proposal and the Commission's suggested variant on it, see Mahan \& Nejelski, Structured Settlement: How to Encourage Good Faith Negotiation Among Parties (1979) (Working Paper, A.B.A. Action Commission to Reduce Court Costs and Delays).

28. See Adams, Would We Rather Fight Than Settle?, 51 FLA. B.J. 496 (1977). 
discourage others. ${ }^{29}$ Furthermore, despite the arguments made, there is no empirical evidence that either the integrity or the efficiency of the judicial process is improved, or indeed affected, by exceptions to the American rule. While the courts clearly have intended and fully expect that the threat of imposition of an opponent's attorney fees deters inappropriate use of limited judicial resources, there has not been any effort to establish clearly the existence of any such relationship. Empirical evidence has simply played no part in the development of judicially imposed exceptions to the American rule. However appropriate it may be for courts to protect the integrity of the judicial process by the imposition of punitive sanctions, there is only speculation as to their effectiveness. An examination of fee shifting by legislatures will show that, like courts (albeit with different goals), they too have proceeded to fashion exceptions to the American rule largely on the faith that their efforts will encourage citizens to participate actively in the enforcement of the laws by asserting their rights under them.

\section{B. Enforcement as Policy Goal}

Laws are to a substantial extent effectuated through the demands of their beneficiaries. Thus, implementation of public policy and compliance with the law are, in part, dependent upon the willingness and ability of the citizenry to assert their rights under the law. However, the implementation and compliance literature has focused almost exclusively on the incentives for compliance and the disincentives for failure to comply. There has developed a substantial literature over the question whether the carrot or the stick is the more effective tool to implement the law. ${ }^{30}$ Missing from the analysis has been consideration of the central role played by the beneficiary of the law in initiating the process of legal mobilization, thereby demanding compliance and threatening to use the power of the state to obtain it. ${ }^{31}$

Much compliance occurs because of expected, implicit or actual threats to employ the power of the state to enforce the law. Laws are thus most often implemented without the intervention of legal professionals or the formal structures of the justice system. Further, when legal professionals, regulatory agencies and/or courts actually do become involved in the enforcement of public policy it is most often in response to the demand of an aggrieved party who will benefit from enforcement. ${ }^{32}$

While much has been made of the limited access to justice of the poor, available evidence indicates that despite much of the rhetoric, most people who want to see a lawyer do so. ${ }^{33}$ Such evidence, however, does not provide any clues as to who might want to use a lawyer if the fees were to be paid by their opponents. Nor does it provide any indication of the limits that the structure of legal fees places on the assertion of legal rights (and subsequent compliance). As one researcher exam-

29. For an analysis of the likely effects on case filings, see Rowe, supra note 11, at 147.

30. Neiman, The Virlues of Heavy-Handedness in Government, 2 LAW \& POL'Y Q. 11 (1980).

31. The author had considered this point in much greater depth elsewhere. See Zemans, Legal Mobilization: The Neglected Role of the Law in the Political System, 77 AM. POL. SCI. ReV. 690 (1983).

32. Cf. R. Kagan, Regulatory Justice: Implementing a Wage-Price Freeze (1978).

33. See B. Curran, The Legal Needs of the Public (1977); Mayhew, Institutions of Representation, 9 LAW \& SOC'Y REV. 401 (1975). 
ining the impact of Supreme Court decisions has commented, the "effectiveness of a specific law depends upon the self-interest of lawyers to bother with it." ${ }_{34}$ The self-interest of lawyers to "bother" is of course directly related to the willingness and ability of clients to pay them. Many matters are screened out of the legal arena under the American rule precisely because it requires everyone to be responsible for his or her own legal fees. In most cases the actual screening is done not by the lawyers, but by potential litigants who determine that the possible benefit is not worth the cost of legal fees. This perceived chilling effect has led to the enforcement exceptions to the American rule.

1. Development of Enforcement Exceptiuns to the American Rule. It has long been believed that the American rule may have an inhibiting effect on enforcement of the law. Bad faith exceptions and the underlying arguments based on judicial system integrity and efficiency have been made by courts probably as long as the American Rule has been in operation. Enforcement exceptions to the Rule also are not new. What distinguishes the history of enforcement exceptions is their source. In contrast to bad faith exceptions, created by courts for the protection of their own integrity, enforcement exceptions have traditionally been made by legislatures.

An early example of a legislatively created mechanism to encourage private enforcement of selected statutes appeared in the form of qui tam actions. Under statutes that establish civil penalties, private citizens were empowered to bring a civil action and, if successful, recover a portion of the penalty for themselves. The rights of qui tam plaintiffs, or informers as they were called, had to be derived from the substantive statute they were seeking to enforce, with no rights to sue under common law. ${ }^{35}$ Fee shifting, like qui tam, has been designed by legislatures to encourage private enforcement. ${ }^{36}$ For example, as early as 1887 Congress dictated the mandatory awarding of attorney fees to successful plaintiffs injured through violation of the Interstate Commerce Act. ${ }^{37}$ Since 1916 the Clayton Act has also provided for a mandatory exception to the American rule. The statute states that a successful plaintiff under it "shall recover. . . the cost of the suit, including a reasonable attorney's fee." 38

As an alternative to mandatory fee shifting, some legislatures have given judges the discretion to award attorney fees to prevailing parties. Consistent with the policy of enforcement, these awards have usually been limited to prevailing plaintiffs. However, as an enforcement tool, and indeed as an inducement to compliance (i.e., as a mechanism of deterrence), discretionary awards would seem to be

34. W. Mutr, LaW and Attitude Ghange vi (1973).

35. See In re Barney Barker, 56 Vt. 14, 21 (1884).

36. The general idea of private enforcement has received much support from the growing law and economics enterprise. See, e.g., Becker \& Stigler, Law Enforcement, Malfeasance, and Compensation of Enforcers, 3 J. Legal Stud. 1 (1974); Landes \& Posner, The Privale Enforcement of Law, 4 J. Legal STud. 1 (1975). In particular those who endorse that perspective oppose as inefficient the very growth of criminal and regulatory efforts at social control.

37. Interstate Commerce Act, ch. 104, 22 Stat. 379 (1887) (codified as amended at 49 U.S.C. $\$ \S 1-22$, $25-27,153(1976))$.

38. 15 U.S.C. $\S 15$ (1976) (emphasis added). 
substantially less effective than a mandatory shifting of fees. Although an examination of statutory fee shifting language is appropriate, apparent distinctions between "mandatory" and "discretionary" awards and between "one-way" and "prevailing party" fee shifting may not be quite so clear in practice. Even without the empirical evidence necessary to verify the practical implications of these distinctions, a review of a few court decisions makes clear the limits of extrapolating from statutory language alone. The civil rights provisions provide a case in point.

Title II of the Civil Rights Act of 1964 provides that the court "in its discretion may allow the prevailing party . . . a reasonable attorney's fee."39 Yet in Newman v. Piggie Park Enterprises, ${ }^{40}$ the Supreme Court, in interpreting the 1964 Civil Rights Act, held that a party seeking to enforce the rights protected by the Act, if successful, "should ordinarily recover an attorney's fee unless special circumstances would render such an award unjust." 41 In other words, the burden is on losing defendants to convince the court that attorney fees should not be assessed against them. The Court supported its interpretation that Congress intended to encourage injured individuals to seek judicial relief by noting that if the intent was only to assess attorney fees against defendants acting in bad faith, no statutory provision would be necessary under long-standing federal court practice of awarding fees to successful plaintiffs where the defense has acted "in bad faith, vexatiously, wantonly, or for oppressive reasons." 42 The Court found similarly in the context of Title VII litigation. ${ }^{43}$ In both cases the Court interpreted the statutes to provide for the ordinary awarding of attorney fees only to prevailing plaintiffs. The question of awarding attorney fees to prevailing defendants was settled for Title VII cases when the Court found that "a district court may in its discretion award attorney's fees to a prevailing defendant in a Title VII case upon a finding that the plaintiff's action was frivolous, unreasonable, or without foundation, even though not brought in subjective bad faith." 44 While that language is somewhat more inclusive than the common law bad faith test that allows for awarding attorney fees without any statutory authorization, it clearly leaves the balance much in favor of the plaintiff.

Central to the Court's above-mentioned interpretation in the Piggie Park case (that successful plaintiffs should ordinarily recover fees) was the determination that seeking an injunction under Title II was not for the benefit of the plaintiffs alone, but rather that they acted as "private attorneys general," vindicating a policy "Congress considered of highest priority." 45 This view is consistent with one part of the enforcement argument that has been particularly influential in the passage of fee shifting statutes at the federal level. That is to say, the private attorney general notion implies that the named plaintiff is acting on behalf of some broader public and that fee shifting is provided legislatively for the purpose

39. 42 U.S.C. $§ 1973$ (1976) (emphasis added).

40. 390 U.S. 400 (1968) (per curiam).

41. Id. at 402 (emphasis added).

42. See id. at 402 n.4.

43. Albemarle Paper Co. v. Moody, 422 U.S. 405 (1975).

44. Christiansburg Garment Co. v. EEOC, 434 U.S. 412, 421 (1978).

45. 390 U.S. at 402 . 
of advancing the public interest. It is, however, the courts rather than the legislatures that have concerned themselves with whether a given statute meets the public interest test. For it has been the courts and not the legislatures that understandably have felt the need to justify using their discretion to award attorney fees where not legislatively directed.

It has been argued that the American rule is least defensible where Congress has provided a private action and litigation protects the general public. ${ }^{46}$ Given a legal system that operates on a market model to the extent of being highly dependent upon individual initiative, it could be argued equally persuasively that the American Rule is indefensible on enforcement grounds for all statutory law. That is to say, whenever a legislative body passes a law, it does so for public policy purposes. Therefore, there is always a public argument to be made for encouraging its enforcement. The desirability of such encouragement is basically a political decision. While such decisions may be defended in terms of the public interest, there are no clearly recognizable criteria for identifying a statute that furthers the public interest. Indeed a review of state statutes that include fee shifting provisions reveals no such clear "public" dimension; for example, Section 6398 of the Texas Statutes allows for a shifting of attorney fees in an action to maintain clean restrooms in railway stations. ${ }^{47}$

The Supreme Court's much discussed rejection, in its 1975 decision in Alyeska Pipeline Service v. Wilderness Society, ${ }^{48}$ of a judicially created private attorney general without express legislative authorization can in fact be viewed as a reassertion of the traditional dichotomy between judically and legislatively authorized fee shifting. It is the legislatures, the Court in effect stated, that make strategic political decisions to provide for fee shifting as an incentive to encourage the bringing of legal claims so as to promote the enforcement of selected laws. Indeed, the Alyeska decision does not appear to be a deviation from any long-standing doctrine. $^{49}$ A review of the cases cited in Wilderness Society $v$. Morton ${ }^{50}$ (the appellate court predecessor to Alyeska) reveals that with the exception of Piggie Park ${ }^{51}$ none of them predates 1970.52 Although Justice Marshall in his Alyeska dissent asserts that the Court "overstates the novelty of the "private attorney general' theory,"53 the basic issue in contention appears to be the derivation of a "public" benefit doctrine from a "common" benefit doctrine.

One long-standing judicially created exception to the American rule has been

46. See Note, Attomeys' Fees: Exceptions to the American Rule, 25 DrakE L. REV. 717 (1976).

47. See Lorenz \& Hunter, Financing Private Enforcement Through Statutes Authorizing Awards of Attorneys' Fees, Council for Public Interest Law 21 (1979) (unpublished manuscript).

48. 421 U.S. 240 (1975).

49. At issue is the question of fee shifting and not the matter of standing to sue, for which there is a long tradition of the "public interest" litigant who lacks a personal stake in the outcome. See, e.g., Henderson v. United States, 339 U.S. 816 (1950).

50. 495 F.2d 1026 (D.C. Cir. 1974).

51. Newman v. Piggie Park Enters., 390 U.S. 400 (1968) (per curiam). See supra notes 40-41 and accompanying text.

52. There are earlier cases that make reference to the need to award costs in the interests of "doing justice," though always with recognition that it is appropriate only in exceptional cases. See, e.g., Rolax v. Atlantic Coast Liner Co., 186 F.2d 473 (4th Cir. 1951).

53. 421 U.S. at 274 (Marshall, J., dissenting). 
the concept of a common fund. Originally designed (for purposes of efficiency) to apply to distributing the costs of litigation to all the beneficiaries of the result, it has been developed over the years into a mechanism for more direct shifting of fees for a common benefit where no monetary relief is granted. ${ }^{54}$ The courts have based this form of fee shifting on the "original authority of the chancellor to do equity in a particular situation." 55 In cases where courts have had to decide whether a private right of action should be implied, they had to "similarly determine whether the special circumstances exist that would justify an award of attorneys' fees." 56 As such, these fee awards began to look more like an enforcement mechanism, a use of fee shifting that traditionally had been eschewed by the courts. Faced with demands for redress of grievances over violations of statutory law, the court moved to an even broader public benefit framework by using "private attorney general" language. But what distinguished Hall $\nu$. Cole and the other so-called common benefit cases from the private attorney general concept argued in Alyeska is the existence of a definable group benefitting from the litigation. Indeed, the argued advantage of the private attorney general exception is precisely that it avoids the need for an ascertainable class of beneficiaries required in the common benefit cases.

The Court's objection to designating private attorneys general as articulated in Alyeska is the resulting necessity for courts, rather than legislatures, to determine just what qualifies a party for private attorney general status when the broader public is the beneficiary of the enforcement sought in the courts. According to the Court, it is not a judicial role to assess the importance of public policies involved in particular cases. Rather, it is a legislative task to determine what policies are of sufficient public interest to warrant fee shifting as an inducement to enforcement, recognizing, as the legislature surely must, that one cost will be some degree of overenforcement.

In fact, the Alyeska decision is perfectly consistent with the origins of the private attorney general concept. The phrase was apparently coined by Judge Frank to denote the quasi-official status of a congressionally authorized plaintiff:

While Congress can constitutionally authorize no one, in the absence of an actual justiciable controversy, to bring a suit . . . there is nothing constitutionally prohibiting Congress from empowering any person, official or not, to institute such a proceeding . . . even if the sole purpose is to vindicate the public interest. Such persons, so authorized, are, so to speak, private Attorney Generals [sic.] $]^{57}$

Although Frank speaks of the vindication of the public interest, it is clear that he is explaining the congressional decision to so authorize the bringing of litigation.

Evidence of Frank's presumption that the designation of a private attorney general would be a legislative decision can be found in the precedents he cites,

54. See Hall v. Cole, 412 U.S. 1 (1973); Mills v. Electric Auto-Lite Co., 396 U.S. 375 (1970).

55. Sprague v. Ticonic Nat. Bank, 307 U.S. 161, 166 (1939).

56. Mills v. Electric Auto-Lite Co., 396 U.S. 375, 391 (1970). It should be noted that this development has been most pronounced in shareholders' derivative actions where the costs are distributed among all shareholders through a fee award against the corporation. See id. at 394. The difficulty of clearly demarcating the difference between a corporation and its shareholders distinguishes these cases from traditional fee shifting between a loser and a winner.

57. Associated Indus. of New York v. Ickes, 134 F.2d 694, 704 (2d Cir. 1943). 
including a Supreme Court decision affirming a qui tam action. ${ }^{58}$ Like the "common informer," the private attorney general, while not directly injured by a legal wrong, is authorized to bring suit to enforce the law. This is not a new concept:

Statutes providing for actions by a common informer, who himself had no interest whatever in the controversy other than that given by statute, have been in existence for hundreds of years in England, and in this country ever since the foundation of our government. ${ }^{59}$

What has been new in recent decades is the proliferation of legislation guaranteeing rights not readily attained by their intended beneficiaries, who are often either unable to sustain litigation or for whom the personal benefit does not justify the inordinate costs of litigation. As at other times, and over other issues, supporters of this legislation sought a mechanism to encourage enforcement and until Alyeska believed that they had found it in attorney fee awards to private attorneys general. Congressional response to Alyeska in the form of Civil Rights Attorneys' Fees Awards Act of $1976^{60}$ was a confirmation of legislative intent to provide a mechanism - in this case a shifting of attorney fees-to encourage the assertion of rights through private enforcement of the law.

It is surely true that many of the more recent federal statutes that include fee shifting provisions do so for the express purpose of encouraging the vindication of a specifically designated public interest. The Civil Rights Attorneys' Fees Awards Act of 1976 is a perfect example. Yet, as already mentioned, for quite some time many federal statutes have authorized fee shifting in litigation between purely private parties in areas such as bankruptcy, consumer protection, and patent and copyright infringement. ${ }^{61}$ The same is true at the state level.

A review of state statutes that authorize fee shifting indicates that they tend to be unidirectional, providing for the awarding of attorney fees only to prevailing plaintiffs rather than the prevailing party as under the British indemnity rule. Those that do authorize fee awards to the prevailing party are more likely to be discretionary than mandatory. This typical one-way shifting of fees to the prevailing plaintiff is consistent with the general enforcement argument. ${ }^{62}$ That is to say, it is intended to have a deterrent effect by facilitating the assertion of rights under law, including, if necessary, the bringing of litigation.

Fee shifting under these conditions is not as much an incentive to private

58. United States $e x$ rel. Marcus v. Hess, 317 U.S. 537 (1943) (upholding the bringing of a qui tam action under the Federal Informers Act, 31 U.S.C.A. $\S \S 231-34$ ) (The Act has been recodified as amended at U.S.C.A. $\S \S 3729-3731$ (West 1983)).

59. Marvin v. Trout, 199 U.S. 212, 225 (1905)

60. 42 U.S.C. $\$ 1988$ (1976).

61. See Sands, Attomey's Fees as Recoverable Costs, 63 A.B.A. J. 510 (1977). For an extensive list of federal fee award statutes, see R. Aronson, Atrorney-Client Fee ArRangements: Regulation and REVIEW 156 app. (1980).

62. Unidirectional fee shifting to prevailing plaintiffs would not deal with the problem raised by the biology professor's case cited earlier. See supra note 19 and accompanying text. It should be noted, however, that the prevailing defendants would have been no worse off had there been statutorily authorized unidirectional fee shifting to prevailing plaintiffs than they were without it and would still have had the malicious prosecution option that they in fact exercised. A standard for assessing costs against a losing plaintiff in Title VII cases could be somewhat beneficial. See, e.g., Christiansburg Garment Co. v. EEOC, 434 U.S. 412 (1978). 
enforcement as qui tam was; rather, awarding attorney fees effectively eliminates the disincentive to enforcement that exists if there is no fee shifting. Yet legislatures have not eliminated this disincentive in any systematic fashion. Instead, it appears that legislative action on this issue as on any other, has been dependent upon the persuasion of interested parties. ${ }^{63}$ This characteristic suggests what may be the real source of enforcement exceptions to the American rule-political demand.

\section{Enforcement Exceptions as Responses to Political Demand. Legislatures typically} act, indeed as representative bodies they are supposed to act, in response to political demands. The American political system has in fact often been criticized for responding to every social ill with yet more legislation. The passage of legislation may itself satisfy the demand, or at least dampen the potency of the political effort that produced the legislation in the first place.

Ineffective implementation of previously legislated policies may generate further political demands. These demands may include pressure for the creation of enforcement incentives and elimination of enforcement disincentives. Responses to demands for effective tools of implementation have included the creation of a number of different structural features of the American legal system. Included among these are contingent fee arrangements, class actions, small claims courts, pro se actions, and treble damages in antitrust cases. ${ }^{64}$ The same can be said about the creation of regulatory agencies and the delegation of enforcement powers to them, and the imposition of criminal penalties that carry with them the publicly funded state prosecutorial apparatus. ${ }^{65}$ Each of these has been created, at least in part, in response to demands for more effective enforcement in particular areas, and with the express purpose of encouraging and facilitating the pursuit of claims. Of these structures, contingent fees are clearly the most direct response to the demand for legal services perceived to be unmet by the distributive effects of the American rule.

The primary argument offered in support of the contingency fee arrangement is indeed relevant only because of every litigant's responsibility to pay his or her

63. It has been suggested that the reason for not extending fee shifting to prevailing defendants may be a judgment that defendants are most often institutions, see Sands, supra note 61. According to one review of state statutes that authorize fee shifting, liability does tend to be in

public and private institutions with litigation resources which tend to be far greater than those enjoyed by most private citizens; that is to say, railroads, banks and other lenders of retail credit, insurance companies, corporate management. . . . and state and local government agencices.

Lorenz \& Hunter, supra note 47, at 21 . Differentiation in rules and procedures for individual versus corporate actors, of course, is not unprecedented in the legal system. See J. Ruhnka \& S. WELlER, Small Claims Courts, A National Examination (1978); Eovaldi \& Meyers, The Pro Se Small Claims Court in Chicago: Justice for the Little Guy, 72 Nw. U.L. REv. 947 (1978).

64. There are, of course, other possibilities. For example, it has been suggested that the inadequacy of governmental enforcement efforts requires the establishment of a taxpayer remedy to recover government money lost through fraud. See Cherminsky, Fraud and Comption Against the Government: A Proposed Statute to Establish a Taxpayer Remedy, 72 J. CRIM. L. \& CRIMINOLOGy 1482 (1981).

65. See Adams, supra note 28; Ball \& Friedman, The Use of Criminal Sanctions in the Enforcement of Economic Legislation: A Sociological View, 17 STAN. L. REV. 197 (1965). Not all alternatives pursued to encourage enforcement are legal structures. Adams, for example, speculates that frustration over the inability legally to pursue legitimate small claims may be responsible for the consumer movement. 
own attorney fees irrespective of outcome. Contingency fee arrangements provide a mechanism for obtaining legal representation when one has a legitimate claim, but lacks sufficient means to pay for a lawyer. The promise of a portion of the proceeds thus encourages representation. However, to describe the contingent fee as a "method of insuring that all citizens can obtain needed legal representation"66 is to overstate its benefits and to fail to acknowledge its limited applicability. For while it may be true that contingency fees developed from a need to finance legal services for the working class, the need itself was a function of the American rule. ${ }^{67}$

With contingent fees meeting only part of the demand, other alternatives emerged that have had the effect of meeting some of the limitations imposed on legal action by the American rule. Class actions for example, by providing for the pooling of many small claims, economically justified the use of contingency fees or common funds to pursue claims otherwise ignored. ${ }^{68}$ Government agencies and criminal prosecutions can similarly pool claims, but more importantly they socialize the costs of representation. ${ }^{69}$ It has even been argued that our increased reliance on government agencies and criminal sanctions to enforce the law may be a direct response to the American rule and its effects. ${ }^{70}$ This is not necessarily to argue that the American rule alone gave rise to these structural changes, but only that some of the perceived need for enforcement left unmet by virtue of the American Rule has been met in part by these structures. Moreover, the claims for private attorney general status and attendant fee-shifting indicate that there is still substantial demand to minimize further the effects of the American rule.

Like contingent fees, reliance on government action too has additional effects, not the least of which is the political screening of cases that voids the distinctiveness of litigation as a means of citizen access to government decisionmaking. From an enforcement perspective, this may have the benefit of public as opposed to privatized decisions as to the direction and intensity of the enforcement effort to be pursued. However, it has been pointed out in a defense of private rights of action generally, that

66. R. ARONSON, supra note 61 , at 119.

67. An argument can be made that contingency fee arrangements are more advantageous than fee shifting because there are no out-of-pocket costs at all and thus no inhibition of claims out of fear of losing and the accompanying burden of paying two sets of legal fees risked under an indemnity rule. It should be noted, however, that lawyers' risk aversion limits the pursuit of high risk cases under contingency fee arrangements. Furthermore, like every structural change, contingency fees brought with them other difficulties including in particular a potential divergence of interest between lawyer and client. See, e.g., Johnson, Lawyers' Choice: A Theoretical Appraisal of Litigation Investment Decisions, 15 LAW \& SOC'Y REV. 567 (1980-81); D. Rosenthal, LaWyer and Client: Who's in Charge? (1974). For a more complete discussion of the contingent fee, see F. MacKinnon, Contingent Fees for Legal Services (1964).

68. According to Foster, class actions in the United States grew out of an equity tradition that "sought to fashion new remedies where old ones have been shown to be inadequate," and that permitted "parties before the court to speak for . . . the interests of absentees in order to avoid a failure of justice or to relieve against unwarranted burdens." Foster, The Status of Class Action Litigation, 4 RESEARCH CONTRIBUTIONS OF THE AMER ICAN BAR FOUndation 1 (1974). Class actions, like each of the structural changes mentioned, have had their critics, in large measure due to the alleged effects that follow from the ambiguous nature of the attorney-client relationship in this form of litigation. For a discussion of this issue, see Developments-Class Actions, 89 HaRv. L. REV. 1318, 1577-1604 (1976).

69. For a discussion of the role of political demands in dictating the form of enforcement (civil or criminal), see Ball \& Friedman, supra note 65.

70. See Adams, supra note 28. 
in the implementation process, administrative bureaucracies sometimes tend to sacrifice the diffused interests of widely scattered beneficiaries in favor of the interests of more cohesive and better-organized groups. ${ }^{71}$

This endorsement of private rights of action also implicitly favors fee-shifting as an enforcement technique. First, without fee-shifting the right to a private cause of action is in many cases meaningless. Second, since there is no public agency designated to pursue claims under most statutes, without fee shifting their beneficiaries are often left unrepresented. Pro-plaintiff fee shifting is another structural alternative to facilitate enforcement through individual demands for compliance. As a result it has the secondary effects of promoting deterrence and facilitating the implementation of public policy. In practice, recent attempts to expand pro-plaintiff fee shifting have been closely tied to the more general effort to provide easier access to legal services.

\section{Fee Shifting and Access to Justice}

It is of course not a new realization that without access to legal representation many of the rights granted by law remain illusory rights. This is particularly true where enforcement relies exclusively upon the initiation of civil actions by private individuals. It is surely true that law serves an educative function ${ }^{72}$ and that some compliance results from the mere fact that the state has authoritatively spoken. As the author has argued here and elsewhere, ${ }^{73}$ however, a substantial portion of compliant behavior is a response to an assertion of right by beneficiaries of the law. To the extent that such assertions cannot effectively be backed by the power of the state, those rights depend upon voluntary compliance. And where the cost of legal services are prohibitive, the power of the state most often cannot be invoked effectively. As discussed previously, the cost of lawyers' services may inhibit legal action either because of the economic status of the claimant or because the claim is too small to justify the investment necessary to obtain redress. Under the American rule even the most meritorious of claims are so inhibited.

It has been suggested that the promotion of negotiated settlements by fee shifting will result in a net increase in the utilization of legal services. ${ }^{74}$ While this may bring some comfort to the legal profession, more is implied. The greater use of legal services also means an extension of services to different kinds of cases (smaller claims) and categories of the population (the less well-to-do).

The access to justice argument, as traditionally defined to focus on exclusion from the judicial system of categories of persons rather than of types of cases, has been used to defend both the American rule and fee shifting. For example, the American rule is often interpreted as representing a more democratic, even populist position. ${ }^{75}$ Yet a study of legal representation of people of moderate means

71. Stewart \& Sunstein, supra note 12 at 1294.

72. See Andenaes, The General Preventive Effects of Punishment, 114 U. PA. L. REv. 949 (1966).

73. See Zemans, supra note 31 .

74. See Sands, supra note 61 , at 515 .

75. Arthur Schlesinger, Jr. makes this argument, but it cannot be sustained on the basis of the obscure historical record. See A. SChlesinger, Jr., THE AGE OF JACkSON (1945). At minimum it can be said that there was great variability in fee arrangements among the states and that, as mentioned earlier, the Amer- 
suggests fee shifting as one means of making legal services more readily available, ${ }^{76}$ although without distinguishing between the effects of one-way and two-way shifting of fees.

With legal service programs both overburdened and threatened with reduction, if not extinction, it has been further argued that awarding attorney fees would allow the private bar to shoulder a significant share of the burden of representing the poor. ${ }^{77}$ Indeed, one critic of government funding of legal services for the poor supports fee shifting as a preferable mechanism for providing adequate representation. He argues that a direct subsidy encourages litigation, however meritorious, by making it profitable for both plaintiffs and lawyers. ${ }^{78}$

The access to justice consideration can also support the American rule. The risk of losing and bearing the burden of paying two sets of attorneys fees may have a chilling effect on litigation. Yet, although litigation is a risky business, a review of court studies indicates that such fears may be exaggerated. For over a wide variety of cases in a number of different American cities plaintiffs are generally the more likely winners. ${ }^{79}$ Of course, if the legal profession is acting appropriately this would be the expected result, for it is the primary gatekeeper to the judicial process and should advise clients to litigate only meritorious cases. The data indicate that despite the riskiness of the adjudicative process, the screening process is operating to limit the cases that come to court to those more likely than not to win. ${ }^{80}$

If one-way pro-plaintiff fee shifting does, as has been argued, increase the real potential (though not necessarily the actual practice) of going to court, then the incentive for asserting legal rights and initiating claims also increases. The limited history of Title VII litigation, and the development of a private "Title VII Bar" are testimony to the impact that pro-plaintiff (as the Court has interpreted Title VII) fee shifting can have. ${ }^{81}$ Here too, however, with fees dependent upon a successful outcome, cases not likely to win are screened out of court. For example, the limited pursuit of individual Title VII claims (as opposed to class actions) by the private bar reflects the inherent difficulty and consequent high risk in proving

ican rule was alleged by the Supreme Court to be the accepted practice, at least in the federal courts, before the nineteenth century. See Arcambel v. Wiseman, 3 U.S. (3 Dall.) 306 (1796).

76. See B. Christiansen, Lawyers for People of Moderate Means 293-94 (1970)

77. McLaughlin also suggests an exception for unsuccessful indigents' obligations to pay opponents' attorney fees unless they acted in bad faith. See McLaughlin, The Recovery of Attomeys' Fees: A New Method of Financing Legal Services, 40 FORDHAM L. REV. 761, 788 (1972).

78. See G. Tullock, Trials on Trial, the Pure Theory of legal Procedure 30 (1980).

79. See Eovaldi \& Meyers, supra note 63 ; R. Hunting \& G. NeuwirTh, Who Sues IN NeW YORK CitY? (1962); Wanner, The Aublic Ordering of Private Relations, Part Two: Winning Civil Courl Cases, 9 LAW \& SOC'Y REV. 293 (1975); Ruhnka \& Weller, supra note 61, at 110-12.

80. That general advantage of the plaintiff and the presumption by legislators of its existence may in part account for the high proportion of fee shifting statutes that award fees only to prevailing plaintiffs and do not indemnify a winning defendant. The growth and nature of those statutes will be discussed later. See infra text accompanying notes 84-108.

81. See Belton, Comparative Review of Public and Private Enforcement of Tille VII, 31 VAND. L. REV. 905 (1978). In addition, a number of the so-called public interest law firms derive a substantial proportion of their budgets from fee awards. The Legal Defunse Fund, for example, is said to derive about one-sixth of its $\$ 6$ million budget from attorney fee awards. Interview with Stephen Wasby, State University of New York at Albany (Oct. 26, 1982) (discussing his research on LDF). For further references to the LDF budget, see Nat'l L.J., June 7, 1982, at 2, col. 3 and Washington Post, May 25, 1982, at 1, col. 2. 
discrimination in individual cases. Were one-way pro-plaintiff fee shifting to be imposed in additional areas of the law, many of the perceived legal wrongs that are not now pursued would be, and many of the claims now ignored by the wrongdoer would not be.

Under the American rule the consumer or the disgruntled neighbor, for example, is often faced with a "so sue me" response to a valid claim. With the cost of legal fees for pursuing the claim prohibitive, given the size of many consumer and neighborhood claims, there is no incentive for the violator to redress the wrong. (Were it not for contingency fees, the same would hold true for larger cases.) Accordingly, there is no incentive to avoid committing the legal wrong in the first place. One objection to this line of argument is that at the same time that pro-plaintiff fee shifting encourages legitimate claims, it may inhibit legitimate defenses and so inappropriately shift the litigative balance. ${ }^{82}$ Another objection is that pro-plaintiff fee shifting encourages frivolous cases and nuisance suits, further exacerbating an already serious caseload problem.

Indeed, as noted in a review of recent books on the litigiousness of American society, fear over caseload per se has grown to the level where "the State Bar of Arizona actually argued that lawyer advertising should be banned because, if people learned of their rights, use of the courts would be increased."83

A telling anecdote from Jethro Lieberman's book on litigiousness describes a suit filed by a twelve-year-old boy against a teacher who refused to pay for damage he admittedly did to the boy's bicycle. ${ }^{84}$ This case would seem to be a perfect example of the excessive litigation and misuse of judicial time that the State Bar of Arizona feared and that has been at the core of the efforts to divert minor disputes from the courts. Yet, it is the seeming pettiness of the case that demonstrates the important role played by the threat of litigation in obtaining compliance with, and enforcement of, the law. According to Lieberman, it was admitted that had it not been for the filing of a lawsuit the acknowledged debt would not have been paid. ${ }^{85}$

This case provides a nice example of the important role played by individuals in encouraging compliance with the law by asserting their own rights. In the aggregate, such individual claims are central to law enforcement. Structural variables such as attorney fee rules that encourage or inhibit such assertions ultimately have an impact on the implementation of public policies. A more specific examination of statutory fee shifting will illustrate the legislative concern with enforcement and access.

82. A variation on this problem occurs under the American rule in cases in which an individual or small corporation must defend itself against the United States government. It is this problem that is directly addressed by the Equal Access to Justice Act, Pub. L. No. 96-481, title II $\S \S 203-04,94$ Stat. 2325 (1980) (codified at 5 U.S.C. $\$ 504$ (1982) and 28 US.C. $\S 2412$ (Supp. 1981)), under which the government must bear its opponents' attorney fees if the bringing of the original suit is determined to have been unwarranted.

83. Andrews, Suing as a First Resort: A Review of Marks's The Suing of America and Lieberman's The Litigious Society, 1981 Am. B. Found. ReSEARCh J. 851, 860.

84. J. LiEBERMAN, THE Litigious SOCIETY 7 (1981).

85. See id. 


\section{Legislatively Authorized Fee Shifting}

In recent years there has been a geometric increase in legislatively authorized fee shifting, particularly at the state level. According to one survey almost all states have some statutorily provided fee shifting. ${ }^{86}$ Some legislative fee shifting provisions, like the Civil Rights Attorney's Fees Awards Act of 1976, are direct responses to demands for facilitating enforcement efforts that are perceived to be inhibited by the American rule. As the concept of fee shifting gains acceptability, substantive statutes are increasingly including-quite self-consciously for enforcement purposes-fee shifting provisions from the outset. At the federal level these include parts of such diverse statutes as the Organized Crime Control Act, ${ }^{87}$ the Freedom of Information $\mathrm{Act}^{88}$ and the Consumer Product Safety Act. ${ }^{89}$

The breadth and diversity of state fee shifting are enormous. Some states have instituted fee shifting on a very large scale, either generally or with reference to a large category of cases. The most extensive fee shifting legislation is found in Alaska, where costs, including attorney fees, are allowed to prevailing parties in all cases unless the court directs otherwise. ${ }^{90}$ Although fee schedules are tied to the monetary value of the case, trial judges in practice enjoy a great deal of discretion in granting awards. The State of Washington has recently passed legislation to provide for attorney fees (as fixed by the court) as costs to the prevailing party in actions for damages of five thousand dollars or less. ${ }^{91}$ This particular statute clearly speaks to precisely that category of cases left without representation under the American rule even with contingency fees allowable. Yet, by providing for two-way fee shifting it also may have the effect of inhibiting the bringing of claims by the threat of a losing plaintiff's having to pay two attorneys' fees. ${ }^{92}$ Arizona now provides for courts to award reasonable attorney fees to the prevailing party in "any contested action arising out of a contract, express or implied." 93

Most states, however, have adopted fee shifting provisions on an issue-by-issue basis. They range over virtually every topic imaginable. In New York, for example, the prevailing plaintiff recovers attorney fees in contests over fraudulent jewelry appraisals. ${ }^{94}$ In Minnesota a mandatory awarding of fees is provided for unfair dairy trade practices. ${ }^{95}$

Many of the fee award statutes are clearly intended to tip the litigation balance to compensate somewhat for the inordinately unequal economic status of dispu-

86. See Lorenz \& Hunter, supra note 46.

87. Pub. L. No. 91-952, 84 stat. 922 (codified as amended in scattered titles of U.S.C.).

88. 5 U.S.C. $§ 552$ (1977 \& Supp. 1983).

89. Pub. L. No. 92-573, 86 Stat. 380 (codified as amended in scattered sections of 15 U.S.C. and 42 U.S.C.).

90. See Note, Award of Altomeys' Fees in Alaska: An Analysis of Rule 82, 4 U.C.L.A.-Al.Aska L. REV. 129 (1974).

91. Wash. Rev. Code AnN. $\$ 4.84250$ (Supp. 1982).

92. It is unclear the extent to which the Washington statute, by providing for prevailing-party awards, acts largely to balance pro-creditor confession of judgment clauses. This, like much of what has been claimed in support of fee shifting, remains an unexplored empirical question.

93. ARIZ. REv. STAT. ANN. § 12-341.01 (1982).

94. N.Y. GeN. BuS. LaW $\S 239-c$ (McKinney Supp., 1982).

95. Minn. Stat. ANn. § 32A-09 subd. 1 (West 1981). 
tants. This phenomenon is a function of political demand being a source of exceptions to the American rule. Such demand often comes from a populist/consumer perspective. As a result, business institutions and government bodies are frequently made liable for attorney fees when they are unsuccessful in litigation. In Michigan, for example, only a prevailing debtor is entitled to attorney fees in cases alleging violations of the collection practices act. ${ }^{96}$ In Florida, only the prevailing taxpayer is entitled to fees in cases arising out of sales of certificates by tax collectors on land on which taxes have been paid. ${ }^{97}$ The Uniform Residential Landlord and Tenant Act (URLTA) also includes a number of fee shifting provisions. ${ }^{98}$ The Ohio statute, for example, provides for attorney fee awards to the tenant or the landlord in selected situations; ${ }^{99}$ according to one study, tenants are the chief beneficiaries. ${ }^{100}$ In contrast to some traditional provisions (e.g., the standard residential lease in the City of Chicago) that provide only for pro-landlord one-way fee shifting, the Uniform Act (in statutory form in at least some states) seems to reflect the growing political influence of the tenant movement. Consistent with the enforcement (and deterrence) hypothesis, governments are in some statutes the beneficiaries of fee awards. In California for example, it is mandatory that prevailing government plaintiffs be awarded attorney fees when violations of the terms of building contracts by contractors have occurred. ${ }^{101}$ Hundreds more statutes could be cited. ${ }^{102}$

In addition to increased legislative consideration, if not acceptance, of fee shifting has come the serious attention officially given to it by the American Bar Association. The ABA's Consortium on Legal Services and the Public went so far in 1977 as to recommend a general shift to an indemnity rule (although with important limitations) to the Association's House of Delegates. ${ }^{103}$ Strong opposition from various quarters within the Association led to a revised and much watered down proposal the next year. The new proposal, also recommended by the Special Committee on Public Interest Practice, basically provided, with some limitation, for a shifting of fees to private parties who prevail against the government. ${ }^{104}$ The content was substantially the same as that passed by Congress in the Equal Access to Justice Act. ${ }^{105}$

Perhaps the best evidence that fee shifting affects enforcement efforts is pro-

96. Mich. Comp. Laws ANN. § 445.257(2) (West Supp. 1982).

97. Fla. Stat. ANn. $§ 197.121$ (West Supp. 1982).

98. UNIFORM Residential LANDLORD AND TENANT ACT (amended 1974).

99. Ohio Rev. Code Ann. $\$ 5321.01$-.09 (Page 1981).

100. See McIntyre, URLTA in Operation: The Ohio Experience, 1980 AM. B. FOUND. RESEARCH J. 587.

101. Cal. Pub. Cont. Code $\$ 5101$ (West 1984).

102. For a survey of the more than 1900 state fee shifting statutes, see Note, State Attorney Fee Shifting Statules: Are We Quietly Repealing the American Rule?, LAW \& ContemP. Probs., Winter 1984, at 321.

103. American Bar Association Recommendation and Report to the House of Delegates from the Consortium on Legal Services and the Public, Rep. No. 117 (Aug. 1977).

104. American Bar Association Recommendation and Report to the House of Delegates from the Consortium on Legal Services and the Public, Rep. No. 129 (Feb. 1978); American Bar Association Recommendation and Report to the House of Delegates from the Special Committee on Public Interest Practice, Rep. No. 130, (Feb. 1979). The ABA Section on Litigation withdrew its own recommendations (Rep. No. 124) and supported those presented by the Consortium.

105. Equal Access to Justice Act $\S \S 4$, Pub. L. No. 96-481, title II, $\S \S 203-04$, 94 Stat. 2325-29 (1980) (codified at 5 U.S.C. $\$ 504$ (1982) and 28 U.S.C. $\$ 2412$ (Supp. 1981)). 
vided by recent federal legislation intended to control abuses of excessive enforcement. The Equal Access to Justice Act purports to control abuse by regulatory agencies through one-way fee shifting against the government. ${ }^{106}$ Actually, the deterrent effect of this fee shifting on government abuse is not clear, since the burden of attorney fees does not fall on the official who makes the decision to pursue a case. Rather the statute specifically states that it is intended "to diminish the deterrent effect of seeking review of, or defending against, governmental action" by providing, in specified situations, costs against the United States, including attorney fees. At the same time it seeks to redress felt burdens of excessive enforcement efforts by a government with virtually unlimited resources against individuals and businesses whose more limited means deter them from asserting their rights.

Concerns about the impact of fee awards are apparently behind the Reagan Administration's efforts to restrict severely both the incidence of fee shifting and the size of the fees awarded. Proposals from the Office of Management and Budget have met strong opposition from both public interest law firms (whose activities they are in large measure intended to curtail) and from the American Bar Association. ${ }^{107}$ Here, as with other arguments over the wisdom of fee shifting, there is little or no evidence of the effects of the provisions being variously attacked or defended. In the case of the Equal Access to Justice Act, for example, available evidence indicates that its use has been too minimal to provide the basis for any meaningful evaluation of its effects; from October 1, 1981, through June 30, 1982, only thirty petitions for expenses and fees were even filed, of which thirteen were granted by the federal courts. ${ }^{108}$

Ignorance of the actual effects of fee shifting has not kept legislatures from adopting it in response to pressure to achieve particular goals. For example, fee shifting may tend to decrease the filing of high risk cases. Therefore, identifiable categories of cases that are typically high risk could be discouraged by providing for fee shifting. With that in mind, the Florida Medical Association persuaded the Florida legislature to enact a law ${ }^{109}$ requiring a shifting of liability for attorney fees to the losing party in medical malpractice cases. ${ }^{110}$ The doctors expected that the high success rate they enjoy in these cases would, under the new rule, have the effect of limiting medical malpractice claims (and therefore settlements and insurance costs).

While high risk claims might decrease, however, there would also be an increase in the small, but low-risk (high-certainty) claims that had not been worth pursuing (given the burden of legal fees) under the previously applicable Amer-

106. See U.S. Senate Committee on the Judiciary, Equal Access to Justice Act, S. REP. No. 253, 96th Cong., 1st Sess. (1979).

107. See Nat'l L.J., Nov. 29, 1982, at 1, col. 4; Statement on Behalf of the American Bar Association Before the Subcommittee on Agency Administration of the Committee on the Judiciary of the United States Senate Concerning Proposals to Amend the Equal Access to Justice Act (Dec. 9, 1982) (mimeo available at ABA Governmental Relations Office, Washington, D.C.).

108. 51 U.S.L.W. 2446 (Feb.1, 1983).

109. 1980 Fla. Laws 67 (codified at FLA. STAT. ANN $\$ 768.56$ (West 1982))

110. See Bodine, Losers Get Legal Tab in Florida, Nat'l L.J., July 7, 1980, at 1. 
ican rule. Moreover, under the new rule, a plaintiff was recently awarded attorney fees of $\$ 4.4$ million in addition to the jury awarded damages of $\$ 14.47$ million. ${ }^{111}$ Such an increase (35\%) in the insurance company's tab is the exact opposite of the medical society's intent.

This example provides a perfect illustration of the central role of political demands in this as in other legislation. Liability for the payment of legal fees, however distributed, has an impact on use of the legal system. And since that entails using the power of the state for selected purposes, it is an advantage many would like to claim. It also illustrates both the complexity and unpredictability of fee shifting.

\section{IV \\ CONCLUSION}

Who receives the protection and benefits of the law is an important normative question in a democratic society. The allocation of legal rights may be an authoritative statement of appropriate behavior, but it is not the equivalent of actual implementation. The judicial system plays a direct role in the implementation process by providing a forum for the individual citizen to invoke the power of the state to enforce a law of which he or she is a beneficiary. Indeed, the very existence of the courts and the implicit threat to use them are often sufficient to evoke substantial compliance.

Access to the use of state power through the courts has been a continuing matter of concern, and not only for the poor or those identifiable categories of persons sometimes defined as "underrepresented."112 In response to demands for greater access, numerous legal structures have been devised and/or modified through the years for the purpose of encouraging the use (and effective threat of use) of the formal legal process. The American rule that disallows fee shifting except under unusual circumstances is one such structure. Like other legal structures that control the use of law, exceptions to it have emerged over the years. These exceptions are, in large measure, a result of political decisions about the appropriate level of enforcement of various laws.

Like other legal structures, the American rule has been manipulated to achieve particular policy goals. Exceptions to it have been variously used as carrots or sticks to promote selected ends. Judicial exceptions have been largely in the form of the stick to punish inappropriate use of the judicial process-in particular bad

111. Von Stetina v. Florida Medical Center, Inc., No. 81-5946 (Fla. Cir. Ct., Broward County, 1982). This case is of further interest because of the circuit court's apparent basis for calculating the attorney fee. In contrast to the typical multipication of hours worked by the fair market value of legal services, the judge in this case seems to have considered the $40 \%$ contingency agreement ( $50 \%$ on appeal) between lawyer and client. This approach could have important implications for the effect of fee shifting statutes in areas of the law in which legal fees traditionally are calculated as a percentage of the award rather than on an hourly fee basis. The district court of appeal, however, rejected the use of a contracted-for contingent fee percentage as a basis for the fee award and reduced the award to a "reasonable" fee of $\$ 1.5$ million. 436 So 2d 1022, 1031-32 (Fla. Dist. Ct. App. 1983). The case is currently on appeal before the Florida Supreme Court (Case No. 64,237).

112. See J. Handler, Lawyers and the Pursuit of Legal Rights (1978). 
faith and vexatious suits. Legislatures, on the other hand, have held out fee awards as a carrot to encourage the implementation of laws that they have determined need incentives to promote enforcement. Although these exceptions have a long history, the demand for the fulfillment of rights perceived to be ineffectively enforced has begun to focus more recently on the American rule. It must be noted, however, that arguments in favor of fee shifting as a means of effecting a more equitable enforcement of the laws typically neglect two very important limitations.

First, discussions of fee shifting exclude from their purview a large protion of the legal business, even the official legal business, of a society. For even under the British indemnity rule, under which attorney fees most closely follow the event, fee shifting is applicable only in contentious matters. ${ }^{113}$ In noncontentious matters one is, of course, responsible for his or her own legal fees, irrespective of outcome. The importance of this limitation is usually ignored in discussions of the appropriate rule to govern attorney fees and the likely impact of fee shifting were it to be more widely adopted. Due to both the adversarial format of the legal system and the great interest in the law as it contributes to the resolution of disputes, it is often forgotten that much of the work of lawyers and even of courts is noncontentious. ${ }^{114}$ With no recognizable adversary to whom fees could be shifted, the entire question of fee shifting is thus irrelevant to the distribution of the bulk of legal services.

The second limitation is a function of a lack of knowledge. There are many "true believers" in the wisdom of fee shifting and just as many who hold an opposing view. However, their beliefs are essentially matters of faith. Fee shifting provisions have very simply never been empirically evaluated. Although the tendency in this country to limit fee shifting to one-way pro-plaintiff awards is consistent with the incentive structure that underlies the enforcement argument, and it is true that selected examples such as Title VII enforcement support the hypothesis that such fee shifting will encourage the implementation of the law, it is very difficult to generalize.

As the court cases interpreting Title II and Title VII so clearly illustrate, statutory language alone may not be enough to determine how fee shifting will be employed. Indeed, even under explicit legislative mandates for fee shifting, courts have often been accused of relying on their own traditional bad faith requirements for the awarding of attorney fees, continuing to view it as largely a punitive rather than an enforcement mechanism. Where legislatures have allowed for judicial discretion, bad faith criteria may be even more likely to be used as the basis for fee awards. Despite careful argumentation, much of it presented in this symposium issue, the fact of the matter is that we simply do not know the effects of attorney fee awards. As noted in these discussions, the effects are likely to vary substantially depending upon the nature of the case and the litigants. Moreover, it must be

113. See Royal Commission on Legal Services, Final. Report 550 (1979). According to one estimate, noncontentious work accounts for $80 \%$ of solicitor' income. Most of that is attributed to conveyancing (transfers of real property) over which solicitors have a monopoly. See R. JACKSON, THE MACHINERY OF JUSTICE IN ENGLAND 418 (1972).

114. See Engel, Legal Pluralism in an American Community: Perspectives on Civil Trial Courts, 1980 AM. B Found. Research J. 425; Friedman \& Percival, A Tale of Two Courts: Litigation in Alameda and San Benito Counties, 10 LAW \& SOC'Y REv. 267 (1976); Zemans, supra note 31. 
recognized that there are three distinct sets of actors whose decisions are likely to be affected (and not necessarily in the same way) by fee shifting: litigants, lawyers, and judges. Each needs careful consideration. Any serious attempt to answer the empirical questions would be an enormous undertaking, but with the new flurry of interest in fee shifting in this country, at both the state and federal levels, we have an obligation at least to begin the inquiry. Although that task is well beyond the scope of this issue, it is a task that warrants undertaking so that the debates over the benefits of attorney fee shifting can be based on evidence rather than faith alone. 